Volume 9. Nomor 1. Januari 2014
Pandecta
http://journal.unnes.ac.id/nju/index.php/pandecta

\title{
Urgensi Pengadilan Tindak Pidana Korupsi Dalam Mewujudkan Peradilan Yang Bersih dan Berwibawa
}

\author{
Imron Safii ${ }^{\bowtie}$
}

Fakultas Hukum, Universitas Negeri Semarang, Indonesia

Permalink/DOI http://dx.doi.org/10.15294/pandecta.v9i1.2999

\section{Info Artikel}

Sejarah Artikel:

Diterima Oktober 2013

Disetujui November 2013

Dipublikasikan Januari 2014

Keywords:

Clean and authoritative

Court; and Anti-Corruption

Court

\begin{abstract}
Abstrak
Penelitian ini bertujuan untuk mengetahui sejauh mana urgensi adanya Pengadilan Tipikor di daerah. Penelitian ini mengunakan metode Kualitatif jenis pendekatan yuridis sosiologis dan validitas data menggunakan teknik trianggulasi. Hasil Penelitian ini menunjukan bahwa penegakan hukum di Pengadilan Tipikor Semarang dari tahun 2011-2013 mengalami peningkatan, maka kinerja Pengadilan Tipikor Semarang semakin meningkat dalam menangani perkara dan serius dalam penegakan hukum terhadap kasus korupsi. Adanya disparitas penjatuhan hukuman dalam kasus yang sama terhadap penyalahgunaan APBD Sragen ditangani majelis hakim yang tidak berintegritas dan tidak bermoral. Urgensi adanya Pengadilan Tipikor, perkara korupsi di Jawa Tengah di tahun 2012 dan 2013 mengalami peningkatan, tetapi dalam putusan yang dijatuhkan oleh majelis hakim mengalami peningkatan yang cukup baik, setelah adanya Pengadilan Tipikor Semarang. Putusan majelis hakim yang diberikan kepada terdakwa kasus korupsi, rata-rata jumlah putusan selama tahun 2011-2013 masih ringan, yaitu antara 0-4 tahun bahkan ada yang diputus bebas, ini membuktikan bahwa pengadilan tipikor masih lemah dan kurang maksimal dalam menjatuhkan hukuman kepada terdakwa kasus korupsi. Disparitas penjatuhan hukuman bagi terdakwa kasus korupsi tidak bisa dihindarkan dan pasti dipakai oleh majelis hakim pengadilan tipikor Semarang karena hakim melihat kasus yang ditangani, sikap terdakwa selama persidangan dan fakta-fakta yang ada di dalam persidangan dan setiap terdakwa pasti berbeda, itu yang menyebabkan terjadinya disparitas penjatuhan hukuman oleh hakim. Urgensi adanya Pengadilan Tipikor di daerah khususnya di Semarang didasari atas ketidakpuasan masyarakat dalam penegakan hukum terhadap kasus korupsi. Pendirian tersebut mempunyai makna dalam mewujudkan pemerintahan yang bersih dan bebas dari korupsi, kolusi dan nepotisme.
\end{abstract}

\begin{abstract}
This study aims to determine the extent to which the absence of urgency in the Corruption Court. This research uses qualitative methods and types of sociological juridical, and the validity of the data using triangulation techniques. The results of this study indicate that enforcement of Semarang Corruption Court in 2011-2013 has increased, the performance of Semarang Corruption Court increasingly serious in handling the case and in law enforcement against corruption. Sentencing disparities in the same case against the misuse of budget Sragen judges are not handled with integrity and immoral. Urgency presence Corruption Court, cases of corruption in Central Java in 2012 and 2013 has increased, but in a decision handed down by a panel of judges has increased quite good, after the Semarang Corruption Court. Decisions of the judges to be given to the accused in corruption cases, the average number of ruling over the years 2011-2013 was mild, which is between 0-4 years old and some even acquitted, the court proves that corruption is still weak and less than the maximum in the sentencing defendant cases of corruption. Disparity in sentencing for convicted corruption can not be avoided and certainly used by the Semarang Corruption Court judges because judges see cases handled, the attitude of the defendant during the trial and the facts in the trial and every defendant is different, that's what causes the disparity sentencing by the judge. Corruption Court in the absence of urgency, especially in the area of Semarang is based on the dissatisfaction of society in the enforcement of the law against corruption. The establishment has the meaning in creating a clean government and free from corruption, collusion and nepotism.
\end{abstract}

$\triangle$ Alamat korespondensi:

Gedung K1, Kampus Sekaran, Gunungpati Semarang

Jawa Tengah Indonesia 50229

E-mail: imron.sf12@yahoo.com
(C) 2014 Universitas Negeri Semarang ISSN 1907-8919 (Cet6k) ISSN 2337-5418 (Online) 


\section{Pendahuluan}

Kekuasaan kehakiman yang bebas dan mandiri berdasarkan buku pedoman perilaku hakim (Code of Conduct) yang diterbitkan oleh Mahkamah Agung Republik Indonesia memuat serangkaian prinsip-prinsip dasar sebagai moralitas dan wajib dijunjung tinggi oleh para hakim Indonesia baik di dalam maupun di luar kedinasannya. Bersikap mandiri termasuk dalam pengertian ini adalah kata bebas, prinsip ini bermakna bahwa kemampuan bertindak sendiri tidak tergantung pada pihak lain, bebas dari campur tangan, dan bebas dari pengaruh siapapun. Kebebasan peradilan adalah prasyarat terhadap aturan hukum dan suatu jaminan mendasar atas suatu persidangan yang adil, oleh karena itu seorang hakim harus menegakkan dan memberi contoh mengenai kebebasan peradilan, baik dalam aspek perorangan, struktur, maupun kelembagaan. Penerapannya antara lain:

1. Seorang hakim wajib menjalankan tugas judisialnya secara bebas atas dasar faktafakta dan bebas dari pengaruh luar, bujukan, tekanan, ancaman baik langsung maupun tidak langsung.

2. Seorang hakim wajib bebas dari hubungan yang tidak patut dengan lembaga eksekutif maupun legeslatif serta kelompok lain yang berpotensi mengancam kemandirian (independensi) hakim dan badan peradilan.

3. Seorang hakim wajib babas dari segala bentuk tekanan dalam pengambilan keputusan.

4. Seorang hakim wajib berperilaku baik guna memperkuat kepercayaan masyarakat terhadap badan peradilan.

Berdasarkan hal di atas, dapat diartikan bahwa kekuasaan kehakiman adalah kekuasaan yang bebas dan mandiri lepas dari pengaruh kekuasaan pemerintah, sehingga seharusnya kekuasaan kehakiman bisa lebih mandiri dan independen dalam pelaksanaan tugas khususnya yang menyangkut masalah korupsi di Indonesia. Pasal 24 Undang-Undang Dasar 1945 tentang Kekuasaan Kehakiman, Pengadilan Tindak Pidana Korupsi (selanjutnya disebut Pengadilan Tipikor) lahir atas dasar lahirnya Undang-Undang Nomor 30 tahun 2002 terutama Pasal 53 yang diujikan ke Mahkamah Konstitusi, yang mendapat permasalahan bahwa terdapat dua kewenangan lembaga pengadilan yang menangani kasus tindak pidana korupsi yaitu Pengadilan Tipikor dan Pengadilan Umum, kemudian atas Putusan Mahkamah Konstitusi Nomor 012-016-019/PUU/IV/2006 yang menetapkan bahwa Pengadilan Tipikor mempunyai konstitusionalitas yang wajib diperhatikan maka putusan tersebut yang harus dijadikan dasar untuk memaknai konstitusionalitas Pengadilan Tipikor. Setelah adanya putusan tersebut maka Undang-Undang Pengadilan Tipikor harus dibuat paling lambat tiga (3) tahun sebagai satu-satunya Peradilan Tipikor yang khusus menangani masalah-masalah korupsi, maka dibentuklah Undang-Undang Nomor 46 tahun 2009 tentang Pengadilan Tipikor, adanya Undang-Undang tersebut tentunya menjadikan terobosan bahwa Pengadilan Tipikor mempunyai payung hukum untuk berdiri sendiri, independen dan mandiri dalam mengatasi perkara korupsi sesuai kewenangan yang terdapat dalam UndangUndang tersebut. Pengadilan Tipikor yang mempunyai fungsi untuk mengadili para pelaku kejahatan korupsi, kadang kala menyimpang dalam pelaksanaanya. Berbagai daerah di Indonesia banyak kasus-kasus yang penangananya tidak maksimal sebagaian besar adalah terhadap Putusan perkaranya yang menyimpang jauh dari harapan masyarakat. Berikut rekap vonis kasus korupsi di Indonesia.

Pemantauan Indonesia Corruption Watch terhadap fenomena vonis kasus korupsi di pengadilan pasca pembentukan Pengadilan Tipikor di seluruh Indonesia (Sem II 2010 - Sem I 2013).

1. Terpantau: 344 kasus korupsi, dengan jumlah terdakwa 756 orang.

2. Vonis bebas/lepas $18,91 \%$.

3. Vonis bersalah $81,09 \%$.

(www.antikorupsi.org, 18 september 2013)

Jika kita melihat dari data tersebut diatas masih sangat jauh dari kata-kata adil untuk kepentingan masyarakat luas terlebih putusan-putusan bebas kadangkala melukai 
Tabel 1. Rekapitulasi vonis korupsi dari tahun 2005 sampai tahun 2010

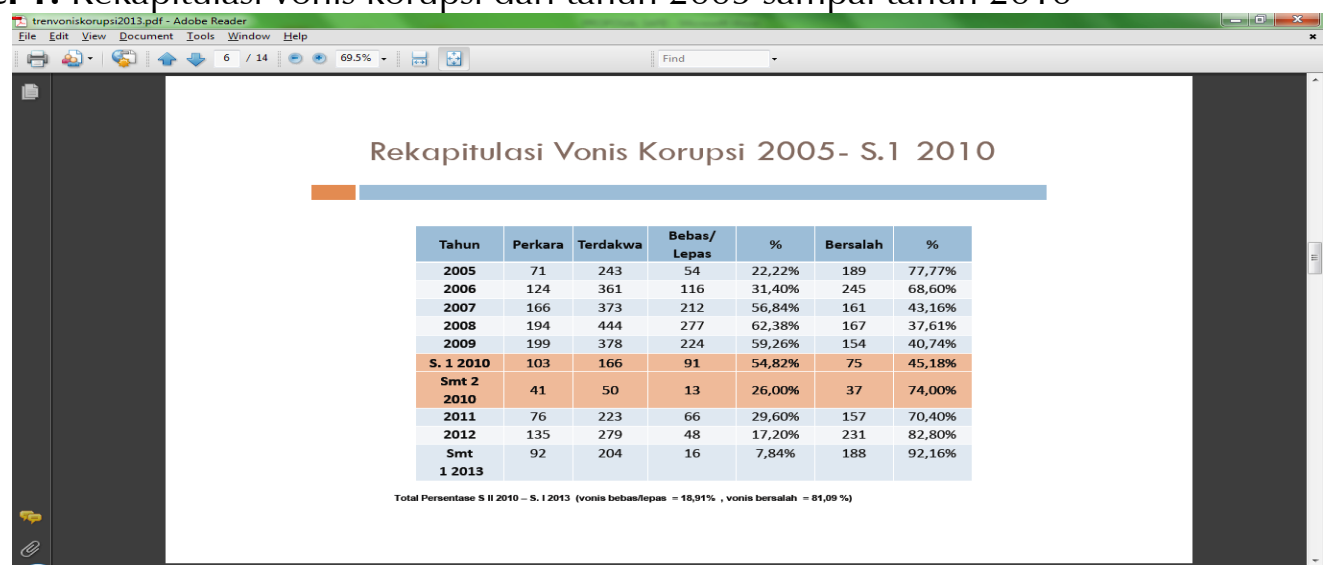

Sumber: (www.antikorupsi.org/sites/antikorupsi.org/.../trenvoniskorupsi2013.pdf, accessed, 18 September 2013)

rasa keadilan bagi sebagian masyarakat yang miskin secara ekonomi, karena yang ada di dalam pikiran masyarakat adalah orang korupsi sudah mendapatkan uang masih bisa bebas berkeliaran pula, tapi itulah kenyataan yang terjadi di Indonesia.

Di Jawa Tengah tidak sedikit adanya kasus-kasus korupsi yang bermasalah dalam penanganannya salah satunya kasus korupsi yang dilakukan ketua DPRD Grobogan M. Yaeni dalam kasus perawatan mobil dinas Sekretariat DPRD Grobogan tahun 20062008, dalam kasus ini hakim di Pengadilan Tipikor Semarang yang menangani kasus tersebut terbukti menerima suap untuk meringankan hukuman terhadap M. Yaeni, kasus ini bermula dari adanya makelar kasus oleh Sri Dartuti (adik M. Yaeni) yang mempunyai teman hakim ad hoc di tipikor Pontianak yang bernama Heru Kisbandoro, kemudian hakim Heru Kisbandoro melobi dan memberikan uang kepada hakim Kartini Marpaung yang kebetulan sebagai Majelis yang menangani kasus M. Yaeni. Dalam kasus ini hakim Pengadilan Tipikor Semarang Kartini Marpaung terbukti bersalah dalam menyalahgunakan kewenanganya dan di jatuhi pidana 8 tahun penjara dan denda 500 juta rupiah, sedangkan hakim Heru Kisbandono dijatuhi pidana 8 Tahun penjara dan denda 800 juta rupiah, sedangkan makelar kasus yaitu Sri Dartuti di jatuhi pidana 5 tahun penjara dan denda 150 juta rupiah. Sedangkan M. Yaeni hanya di jatuhi pidana 2 tahun 5 bulan pen- jara dan denda 50 juta rupiah. (http://hukum. tvonenews.tv, 14 Desember 2012)

Selain dari kasus tersebut ada beberapa kasus lain yang melibatkan hakim Pengadilan Tipikor Semarang yang memutus bebas mantan Bupati Sragen dalam dugaan kasus korupsi pendepositoan uang APBD Sragen 2003-2010 ke Bank Perkreditan Rakyat (BPR) Djoko Tingkir, dari putusan bebas tersebut Kejaksaan Tinggi Jawa Tengah tidak terima atau tidak puas dengan penjatuhan pidana terhadap mantan Bupati Sragen tersebut dan kemudian mengajukan kasasi ke Mahkamah Agung yang kemudian Mahkamah Agung memvonis bersalah kepada mantan Bupati Sragen tersebut dan dijatuhi pidana 7 tahun penjara dan denda Rp 200 juta dan juga diwajibkan membayar uang pengganti kerugian negara sebesar Rp 11 miliar subsider lima tahun penjara.(http://www.tempo.co, 14 Desember 2012)

Dilihat dari data diatas menunjukan bahwa lembaga negara setiap tahunnya terlibat berbagai kasus yang menyangkut masalah korupsi, tidak lain halnya terhadap penegak hukum yaitu hakim Pengadilan Tipikor, ini merupakan suatu hal yang perlu di perhatikan secara serius karena pengadilan merupakan lembaga yudikatif yang tugasnya adalah mengadili para pelaku tindak pidana korupsi. Sehingga dari latar belakang diatas penulis tertarik untuk meneliti dengan judul "Analisis Yuridis Terhadap Urgensitas Kebera- 
daan Pengadilan Tindak Pidana Korupsi Di Daerah Yang Bersih Dan Berwibawa". bawa:

Teori Peradilan yang bersih dan berwi-

Badan Peradilan Indonesia yang agung, secara ideal dapat diwujudkan sebagai sebuah badan peradilan yang baik, yaitu:

1. Melaksanakan fungsi kekuasaan kehakiman secara independen, efektif, dan berkeadilan.

2. Didukung pengelolaan anggaran berbasis kinerja secara mandiri yang dialokasikan secara proporsional dalam APBN.

3. Memiliki struktur organisasi yang tepat dan manajemen organisasi yang jelas dan terukur.

4. Menyelenggarakan manajemen dan administrasi proses perkara yang sederhana, cepat, tepat waktu, biaya ringan dan proporsional.

5. Mengelola sarana prasarana dalam rangka mendukung lingkungan kerja yang aman, nyaman, dan kondusif bagi penyelenggaraan peradilan.

6. Mengelola dan membina sumber daya manusia yang kompeten dengan kriteria obyektif, sehingga tercipta personil peradilan yang berintegritas dan profesional.

7. Didukung pengawasan secara efektif terhadap perilaku, administrasi, dan jalannya peradilan.

8. Berorientasi pada pelayanan publik yang prima.

9. Memiliki manajemen informasi yang menjamin akuntabilitas, kredibilitas, dan transparansi.

10. Modern dengan berbasis Teknologi Informatika terpadu. (Cetak Biru Pembaruan Peradilan Mahkamah Agung, 2010: 14)

Secara filosofis pengadilan merupakan tempat masyarakat menyelesaikan segala persoalannya, meskipun pada hakikatnya pengadilan adalah sebuah arena pertarungan bagi warga negara untuk memenangkan keadilan yang diklaimnya, dalam sebuah upaya memenangkan pertarungan segala upaya dilakukakan, secara legal tentunya diharapkan, akan tetapi siapa yang bisa menjamin mereka tidak melakukan hal-hal yang ilegal, tanpa adanya akuntabilitas terhadap kekuasaan kehakiman niscaya keadilan tidak akan dapat dilayani.

Dalam mendukung akuntabilitas kekuasaan kehakiman adalah untuk mencegah para hakim dan lembaga mereka dari penyalahgunaan kewewenangan dan pelaksanaan akuntabilitas tersebut dapat menunjukkan bahwasanya sistem kekuasaan kehakiman dan hakim seharusnya berfungsi sesuai dengan segala macam petunjuk tertulis dan tidak tertulis serta aturan-aturan hukum yang ada. Untuk suatu peradilan yang baik harus dibutuhkan:

1. Hakim-hakim yang berkualitas baik. Seleksi dan penggajian adalah penting sekali.

2. Kemungkinan bagi si warga untuk selalu mempunyai jalan (minta bantuan) ke seorang hakim.

3. Pemutusan dalam persengketaan itu dalam waktu yang wajar.

4. Penetapan suatu hukum acara yang baik, yang mana dasar-dasar tata cara yang elementer (seperti didengar dan mendengarkan) telah ditentukan.

5. Kemungkinan-kemungkinan naik banding dan atau kasasi untuk memperbaiki kesalahan-kesalahan yang mungkin ada dari hakim-hakim rendahan.

6. Jaminan-jaminan bahwa keputusan-keputusan para hakim juga sungguh-sungguh dilaksanakan. (Hadjon, 2011: 292)

Mewujudkan peradilan bersih dan bebas adalah tanggung jawab bersama stake holder bangsa. Semua elemen harus menyadari bahwa peradilan bersih akan menghasilkan multi efek keadilan sosial yang akan mengikis habis korupsi dan nepotisme dalam berbagai sektor kehidupan termasuk di dalamnnya pengadilan. Untuk mewujudkan peradilan bersih maka hakim dalam memutus perkara harus berpedoman dengan kode etik dan perilaku hakim. Meski demikian, hakim juga membutuhkan pengawasan lembaga lain seperti Komisi Yudisial agar berjalan sesuai rasa keadilan. Mewujudkan peradilan yang bersih dan berwibawa tidak langsung bisa terlaksana tanpa adanya dukungan dari berbagai pihak yang berkepentingan dalam proses di pengadilan. Berikut beberapa un- 
sur untuk mewujudkan peradilan yang bersih adalah:

1. Penguatan legalitas fungsi independensi dan transparansi

2. Transparansi rekruitmen pejabat peradilan

3. Transparansi internal dalam proses peradilan

4. Informasi dan keuangan

5. Efektifitas sanksi bagi pelanggar

6. Efektifitas lembaga pengawas eksternal

7. Kemudahan akses Beria Acara Perkara (BAP), dakwaan, dan putusan

8. Transparansi nalar hukum dari aspek moralitas hukum, kepastian hukum dan penghormatan Hak Asasi Manusia (HAM) terdakwa atau para pihak (Buletin Komisi Yudisial. 2009. Vol IV: 9).

Perwujudan lembaga peradilan sebagai tonggak terdepan di dalam pencarian suatu keadilan adalah hal yang diidamkan masyarakat. Keadilan adalah tujuan lembaga peradilan didalam menjalankan fungsi dan wewenangnya masing-masing. Dalam mencapai tujuannya lembaga peradilan terdapat berbagai organ pelaksana, diantaranya yang paling penting adalah keindepedensian pelaksana peradilan tersebut bebas dari berbagai kepentingan dari luar yang akan mempengaruhi keadilan tersebut.

\section{Metode Penelitian}

Penelitian ini menggunakan pendekatan penelitian kualitatif, sedangkan Jenis penelitian ini secara yuridis-sosiologis. Secara yuridis berarti penelitian ini bisa mencakup penelitian terhadap asas-asas hukum, sistematika hukum, taraf sinkronisasi hukum, sejarah hukum, dan perbandingan hukum secara sosiologis berarti penelitian ini terdiri dari penelitian terhadap identifikasi hukum (tidak tertulis) dan penelitian terhadap efektifitas hukum (Soekanto, 1986: 51).

\section{Hasil dan Pembahasan}

\section{a. Kinerja Proses Penegakan Hukum di Pengadilan Tipikor Semarang} Terbentuknya Pengadilan Tipikor Se- marang pada tanggal 17 Desember 2010, sampai saat ini belum mencerminkan kewibawaan dan integritas keadilan. Kalau kita melihat banyak kasus-kasus korupsi yang divonis rendah oleh majelis hakim tipikor Semarang, bahkan masih ada yang divonis bebas, hal ini merupakan salah satu rangking buruk lembaga peradilan kita, karena pandangan masyarakat tentang kewibawaan peradilan dan kebersihan Peradilan Tindak Pidana Korupsi ternyata masih jauh dari apa yang diharapkan oleh masyarakat. Selain itu terdapat peningkatan kasus korupsi di berbagai daerah, di Jawa Tengah sendiri dari tahun 2011 sampai dengan tahun 2013 terdapat peningkatan korupsi yang sangat memprihatinkan, bahkan jawa tengah termasuk daerah yang tingkat korupsinya paling tinggi di Indonesia (Laporan Monitoring KP2KKN Jawa Tengah tahun 2011). Berikut data perkara kasus korupsi di Jawa Tengah.

Berdasarkan data KP2KKN Jawa Tengah dapat diketahui bahwa kasus korupsi di Jawa Tengah semakin meningkat, pada tahun 2012 kasus korupsi di Jawa Tengah meningkat $100 \%$ (seratus persen) dari tahun 2011, sedangkan tahun 2013 juga mengalami peningkatan kasus yang cukup banyak. Jika kita mengamati perkembangan kasus di Jawa Tengah sejak berdirinya Pengadilan Tipikor Semarang pada 17 Desember 2010, peningkatan jumlah kasus yang semakin bertambah membuktikan bahwa, sejak berdirinya Pengadilan Tipikor Semarang korupsi di Jawa Tengah tidak semakin berkurang, akan tetapi berkembang pesat peningkatanya. "Adanya peningkatan kasus korupsi di Jawa Tengah dikarenakan putusan-putusan Pengadilan Tipikor tidak memberikan efek jera dan majelis hakim tidak menjatuhkan hukuman maksimal, itu yang membuat orang tidak takut untuk berbuat korupsi". (Eko Haryanto, 24 Januari 2014). Untuk mengetahui kinerja Pengadilan Tipikor Semarang, penulis mengamati putusan-putusan yang dijatuhkan oleh majelis hakim Pengadilan Tipikor Semarang, karena wibawa Pengadilan Tipikor adalah melihat dari putusan yang dijatuhkan,. Berikut rekap vonis penjatuhan hukuman oleh majelis hakim Pengadilan Tindak Pidana Korupsi Semarang. 
Tabel 2. Jumlah Kasus korupsi di Jawa Tengah Tahun 2011-2013

\begin{tabular}{lcc}
\hline Tahun & Jumlah Kasus & Potensi Kerugian Keuangan Negara \\
\hline $\mathbf{2 0 1 1}$ & 102 kasus & Rp. 142,6 Milyar \\
$\mathbf{2 0 1 2}$ & 215 kasus & Rp. 381 Milyar \\
$\mathbf{2 0 1 3}$ & 222 kasus & Rp. 110,942 Milyar \\
\hline Sumber: Analisis database KP2KKN
\end{tabular}

Sumber: Analisis database KP2KKN Jawa Tengah Tahun 2013

Berdasarkan analisis data penulis dapat diketahui bahwa putusan yang ada di Pengadilan Tipikor Semarang masih ringan, bahkan masih terdapat putusan bebas yang dijatuhkan oleh majelis hakim Pengadilan Tipikor Semarang. Berikut penulis akan memberikan perbandingan dalam sidang kasus korupsi mantan Bupati Sragen Untung Wiyono yang di vonis bebas oleh Pengadilan Tipikor Semarang, yaitu perbandingan antara tuntutan Jaksa Penuntut Umum dan Putusan Pengadilan Tipikor.

Melihat perbandingan antara tuntutan dari Jaksa Penuntut Umum dan Putusan yang dijatuhkan oleh Majelis Hakim Pengadilan Tipikor Semarang sangat jauh dari apa yang diharapkan. Jaksa Penuntut Umum melalui surat dakwaan dan tuntutannya memberikan semangat pemberantasan korupsi, melalui dakwaan yang dibuat Jaksa Penuntut Umum memberikan tuntutan yang maksimal, akan tetapi tuntutan tersebut bertolak belakang dengan yang dilakukan oleh majelis hakim yaitu tidak memberikan putusan yang sesui keadilan masyarakat, dan lebih menganggap dakwaan Jaksa Penuntut umum seperti tidak ada. Perkembangan kasus korupsi yang masuk di Pengadilan Tipikor Semarang tidak di imbangi dengan proses penegakan hukum yang bersih, dari beberapa putusan majelis hakim masih ada yang di putus bebas, salah satu kasus yang sangat memprihatinkan adalah ketika kasus mantan Bupati Sragen Untung Wiyono yang di putus bebas oleh Majelis Hakim Pengadilan Tipikor Semarang saat itu, ini sangat tidak masuk akal karena dalam putusan lainya Sekretaris Daerah Sragen Kushardjono dan Kepala Badan Pengelolaan Keuangan Daerah Sragen Sri Wahyuni masing-masing di putus bersalah dan terbukti melakukan penyalahgunaan APBD Sragen, namun Untung Wiyono sebagai otak pelaku yang memerintah terhadap Sri Wahyuni dan
Kushardjono untuk melakukan pendepositoan uang tersebut malah di bebaskan. Melihat putusan yang tidak memberikan rasa adil di masyarakat, Kejaksaan Tinggi Jawa Tengah melakukan kasasi ke Mahkamah Agung dan hasilnya Untung Wiyono di vonis bersalah dengan putusan pidana 7 tahun penjara, denda Rp. 200.000.000 (dua ratus juta rupiah) dan mengganti kerugian keuangan $\mathrm{Ne}$ gara sebesar Rp. 11.000.000.000, (sebelas Milyar rupiah), putusan ini sangat bertolak belakang dengan putusan pengadilan tingkat pertama yaitu Pengadilan Tipikor Semarang. Perbandingan putusan yang dijatuhkan oleh Mahkamah Agung dengan Pengadilan Tipikor Semarang membuktikan bahwa terdapat masalah dalam penanganan kasus mantan Bupati Sragen di Pengadilan Tipikor Semarang.

Dengan adanya indikasi permasalahan penanganan perkara di Pengadilan Tipikor Semarang, penulis melakukan wawancara terhadap hakim Pengadilan Tipikor Semarang untuk mengetahui fakta dan latar belakang permasalahan dalam penanganan perkara. Berikut pendapat dari hakim terhadap putusan bebas tersebut.

Putusan bebas terhadap mantan Bupati Sragen Untung Wiyono terjadi karena kasus tersebut ditanganani oleh majelis hakim yang tidak berintegritas dan tidak bermoral yang baik, secara logika kalau melihat putusan yang dijatuhkan kepada Kepala Dinas Pendapatan Pengelolaan Keuangan Aset Daerah (DPPKAD) dan Sekda Kabupaten Sragen yang di hukum sedangkan mantan Bupati Sragen Untung Wiyono sebagai inisiator dalam kasus tersebut di vonis bebas, tetapi Pengadilan Tipikor tingkat pertama bukan penentu terakhir dalam penjatuhan hukuman, namun kita melihat bahwa persoalan hakim adalah integritas dan moral, bisa dilihat siapa majelis hakim yang menangani kasus tersebut dan 
Tabel 3. Rekap Vonis Pengadilan Tindak Pidana Korupsi Semarang Tahun 2011-2013

\begin{tabular}{lcccc}
\hline Tahun & Bebas & $\begin{array}{c}\text { Ringan } \\
(0-4 \text { tahun })\end{array}$ & $\begin{array}{c}\text { Sedang } \\
(4,1-10 \text { tahun })\end{array}$ & $\begin{array}{c}\text { Berat } \\
(>\mathbf{1 0} \text { tahun })\end{array}$ \\
\hline $\mathbf{2 0 1 1}$ & 1 Putusan & 47 Putusan & 7 Putusan & - \\
$\mathbf{2 0 1 2}$ & 8 Putusan & 119 Putusan & 24 Putusan & - \\
$\mathbf{2 0 1 3}$ & 1 Putusan & 99 Putusan & 3 Putusan & - \\
Jumlah & 10 putusan & 265 putusan & 34 putusan & - \\
\hline
\end{tabular}

Sumber: Hasil analisis data penulis Tahun 2014

sekarang majelis hakim yang menangani kasus tersebut di hukum. (Wawancara dengan Marsidin Nawawi, 27 Januari 2014)

Kewibawaan Institusi peradilan dilihat dari putusan yang dijatuhkan oleh majelis hakim, karena Pengadilan Tipikor merupakan titik pemberantasan korupsi di negara ini, terlebih adalah Pengadilan Tipikor di daerah yang sangat strategis posisinya dalam memberantas korupsi yang ada di daerah. Proses penegakan hukum di Pengadilan Tipikor daerah tidak lepas dari sistem yang ada di negara ini, mulai dari peraturan perundang-undangan dan mekanisme pengawasan internal hakim sendiri, persoalan itu sangat mendasar karena pengawasan yang kurang maksimal atau perundang-undangan yang lemah juga tidak akan merubah apa-apa dalam pemberantasan korupsi

Sistem di Indonesia selama ini sudah baik, upaya untuk menjatuhkan hukuman yang maksimal bagi koruptor adalah Undang-ndang Tindak Pidana Korupsi disandingkan dengan Undang-Undang Tindak Pidana Pencucian selain itu persoalan utama untuk memperbaiki kinerja Pengadilan Tipikor Semarang agar vonis yang dijatuhkan lebih maksimal adalah rekrutmen hakim harus lebih transparan dan lebih kredibel. (Wawancara dengan Eko Haryanto, 24 Januari 2014)

Perlu adanya evaluasi tentang keberadaan Pengadilan Tipikor mulai dari regulasi, sistem, hingga kinerja dan pengawasan terhadap hakim. Menyalahkan Pengadilan Tipikor secara membabi-buta tidak tepat, karena Pengadilan Tipikor hanya menjadi subordinasi dari sistem peradilan pidana (crimi- nal justice system) yang merupakan kerangka besar di bawah Mahkamah Agung. Kebobrokan sistem tentu akan berimbas juga kepada keberadaan Pengadilan Tipikor. Terlebih lagi, permasalahan dunia peradilan tak hanya ketika berada di tahap pengadilan. Banyak kasus korupsi yang memang menunjukkan bahwa ada upaya sistematis dari aparat penegak hukum untuk membuat jerat hukum yang rapuh, seperti dakwaan lemah serta barang bukti yang dikaburkan. Keluhan-keluhan dari masyarakat terkait kompetensi hakim, terutama hakim ad hoc, juga menjadi hal yang fundamental untuk pembenahan Pengadilan Tipikor. Minimnya kompetensi hakim terutama untuk hukum acara dan substansi perkara menjadi tanggung jawab Mahkamah Agung untuk mengatasinya. Proses rekrutmen hakim seharusnya disertai dengan mekanisme pengembangan kompetensi, jelas terlihat bahwa Mahkamah Agung kewalahan mengurus Pengadilan Tipikor yang ada di setiap wilayah provinsi di Indonesia, karena banyak permasalahan disana. Kinerja Pengadilan Tipikor Semarang dalam penegakan hukum selama ini belum maksimal hal ini dibuktikan dengan beberapa putusan yang lemah, ratarata putusan yang dijatuhkan oleh Pengadilan Tipikor Semarang dibawah 5 tahun dan tergolong putusan yang sangat ringan bagi seorang koruptor. Putusan yang lemah oleh Pengadilan Tipikor Semarang masih dikaitkan dengan faktor tingkat indepedensi hakim.

\section{b. Legal Reasoning Hakim}

Dalam konteks penegakan hukum, disparitas penjatuhan hukuman erat kaitanya 
Tabel 4. Putusan terhadap mantan Bupati Sragen Untung Wiyono

\begin{tabular}{|c|c|c|c|}
\hline $\begin{array}{l}\text { Penanganan } \\
\text { Kasus }\end{array}$ & Tuntutan JPU & Putusan & Keterangan \\
\hline $\begin{array}{l}\text { Pengadi- } \\
\text { lan Tipikor } \\
\text { Semarang }\end{array}$ & $\begin{array}{l}\text { Pidana } 10 \text { tahun pen- } \\
\text { jara dengan denda Rp. } \\
500.000 .000 \text { dan diwa- } \\
\text { jibkan membayar uang } \\
\text { penggati sebesar Rp. } \\
11.216 .045 .352 \text { (sebelas } \\
\text { milyar dua ratus enam be- } \\
\text { las juta empat puluh lima } \\
\text { ribu tiga ratus lima puluh } \\
\text { dua rupiah) }\end{array}$ & Putusan bebas & $\begin{array}{l}\text { Perbandingan putu- } \\
\text { san antara Pengadi- } \\
\text { lan Tipikor Semarang } \\
\text { dengan Mahkamah } \\
\text { Agung, menunjukan } \\
\text { bahwa proses pen- } \\
\text { egakan hukum di Pen- } \\
\text { gadilan Tipikor Sema- } \\
\text { rang bermasalah kalau }\end{array}$ \\
\hline $\begin{array}{l}\text { Mahkamah } \\
\text { Agung }\end{array}$ & Kasasi & $\begin{array}{l}\text { Pidana } 7 \text { tahun } \\
\text { penjara, denda Rp. } \\
200.000 .000 \text { (dua } \\
\text { ratus juta rupiah) dan } \\
\text { mengganti kerugian } \\
\text { keuangan Negara } \\
\text { Rp. 11.000.000.000 }\end{array}$ & $\begin{array}{l}\text { dilihat dari segi putu- } \\
\text { sannya, karena sangat } \\
\text { berbanding terbalik } \\
\text { antara putusan yang } \\
\text { di jatuhkan oleh MA }\end{array}$ \\
\hline
\end{tabular}

Sumber: Analisis Penulis tahun 2014

dengan tidak independennya hakim dalam menangani suatu kasus. Masyarakat umum cenderung membandingkan penjatuhan pidana antara satu kasus dengan kasus korupsi lainnya mengenai berat ringan pidana yang diterapkan dalam putusan, masyarakat berpandandangan bahwa pelaku korupsi umumnya dilakukan oleh pejabat negara yang mempunyai latar pendidikan tinggi, sedangkan kalau hukuman bagi pelaku korupsi itu disamakan dengan pelaku pidana ringan, itu sangat menciderai keadilan masyarakat Disparitas putusan pidana dianggap sebagai isu yang mengganggu dalam sistem peradilan pidana, dan berpengaruh pada cara pandang dan penilaian masyarakat terhadap peradilan, karena dapat dilihat sebagai wujud dari ketidakadilan, akan tetapi disparitas merupakan suatu hal yang tidak bisa di hindarkan dari kebebasan hakim dalam memberikan putusan.

Disparitas sebenarnya timbul dari perkara itu sendiri, hakim memutus perkara ber- dasarkan kebebasan dan keyakinan hakim serta petunjuk-petunjuk yang dibentuk sedikitnya dari dua alat bukti yang di temukan didalam fakta-fakta persidangan, hakim tidak melihat putusan-putusan yang lainya tetapi hakim akan konsen pada putusan yang dia hadapi berdasarkan fakta persidangan dan tergantung di setiap perkara itu sendiri. (Wawancara dengan Marsidin Nawawi, 27 Januari 2014)

Ada banyak faktor yang menyebabkan terjadinya disparitas putusan, tetapi pada akhirnya hakim yang paling menentukan terjadinya disparitas. "Asas nulla poena sine lege yang memberi batas kepada hakim untuk memutuskan sanksi pidana berdasarkan takaran yang sudah ditentukan dalam peraturan perundang-undangan, meskipun ada takaran, masalah disparitas akan tetap terjadi karena jarak antara sanksi pidana minimal dan maksimal dalam takaran itu terlampau besar". (Zulfa, 2011: 33).

Disparitas dalam perkara pidana ko- 
rupsi jelas berbeda, sebagai contoh, perkara korupsi yang dilakukan oleh orang yang megerti dan paham tentang hukum seperti halnya kasus Djoko Susilo itu sangat berbeda dan harus mendapatkan hukuman yang maksimal. Disparitas pidana dalam perkara korupsi hal yang wajib dan harus terjadi karena:

1. Perkara yang terjadi berbeda (tergantung perkara).

2. Perilaku dan karakter dari terdakwa kasus korupsi berbeda.

3. Perbedaan jabatan setiap pelaku korupsi.

4. Profesi pelaku korupsi.

5. Kebebasan dan indepedensi hakim dalam memberikan putusan. (Wawancara dengan Jhon Halasan Butar-Butar, 9 Januari 2014)

Disparitas dalam penjatuhan hukuman yang dilakukan oleh majelis hakim seringkali tidak masuk akal, lebih lagi ketika satu kasus yang dilakukan bersama-sama akan tetapi putusanya berbeda-beda. Contoh disparitas penjatuhan hukuman terhadap koruptor pernah terjadi juga di Pengadilan Tipikor Semarang, ketika kasus penyalahgunaan uang APBD oleh mantan bupati Sragen. Untung Sarono Wiyono Sukarno, kasus ini bermula ketika uang APBD Sragen di simpan di BPR Djoko Tingkir yang menurut Undang-Undang itu merupakan sesuatu yang salah dan tidak dibenarkan secara hukum, hal ini tercantum dalam penjelasan Pasal 193 Ayat (1) UndangUndang Nomor 32 Tahun 2004 Tentang Pemerintah Daerah yang menyatakan bahwa "Dana APBD tidak boleh disimpan atau di depositokan di bank nonpemerintah". Pasal ini secara tegas memberikan larangan untuk menyimpan atau mendepositokan dana APBD di bank non pemerintah, dengan kata lain APBD hanya bisa di simpan atau di depositokan ke bank pemerintah.

Dalam kasus ini Sekretaris Daerah Kabupaten Sragen sebagai pelaku atas perintah Bupati Sragen melakukan transaksi untuk mendepositokan uang APBD Sragen sebagai jaminan untuk mendapatkan pinjaman dari BPR Djoko Tingkir, lebih parahnya uang pinjaman dari BPR Djoko Tingkir itu digunakan untuk kepentingan pribadi. Dalam kasus penyalahgunan uang APBD Sragen banyak pe- jabat pemerintah Daerah Sragen yang terlibat dalam kasus ini, diantaranya mantan Bupati Sragen Untung Wiyono, Sekretaris Daerah Sragen Khushardjono, dan kepala Badan Pengelolaan Keuangan Daerah Sragen Sri Wahyuni. Dalam kasus ini Sekretaris Daerah Kabupaten Sragen periode (2004-2010), Kushardjono dijatuhi hukuman 4 (empat) tahun 6 (enam) bulan penjara dan denda Rp.100.000.000 (seratus juta rupiah), dalam putusan majelis hakim Kushardjono terbukti secara sah dan meyakinkan melakukan tindak pidana korupsi, melanggar Pasal 3 ayat (1) junto Pasal 18 Undang-Undang Nomor 31 Tahun 1999 sebagaimana telah diubah dan ditambah dengan Undang-Undang Nomor 20 Tahun 2001tentang Pemberantasan Tipikor junto Pasal 55 ayat (1) KUHP.

Perbuatan terdakwa dilakukan bersama dengan Mantan Bupati Sragen, Untung Wiyono Dan Mantan Kepala Dinas Pengelolaan Kepala Dinas Pendapatan Pengelolaan Keuangan Aset Daerah (DPPKAD), Sri Wahyuni sehingga merugikan keuangan negara senilai Rp11,2 Milyar, akan tetapi Untung Sarono Wiyono Sukarno, selaku Bupati Sragen sekaligus sebagai inisiator seorang yang memberikan perintah terhadap terjadinya penyalahgunaan APBD di hukum bebas oleh Pengadilan Tipikor Semarang, walaupun akhirnya dijatuhi hukuman penjara oleh Mahkamah Agung atas kasasi Kejaksaan Tinggi Jawa Tengah selama 7 (Tujuh) tahun, membayar denda Rp.200.000.000 (dua ratus juta rupiah) dan diwajibkan mengembalikan uang pengganti senilai Rp.11.000.000.000. (sebelas Milyar rupiah), akan tetapi jika dilihat dari penjatuhan hukuman oleh hakim Pengadilan Tipikor Semarang memang menceridai keadilan di masyarakat, itulah disparitas yang menjadi kebebasan bagi hakim. Berikut kasus korupsi penyalahgunaan Uang APBD Sragen yang dilakukan oleh Pejabat Pemerintah Daerah Sragen

Perbandingan putusan yang dijatuhkan oleh Majelis Hakim Pengadilan Tipikor Semarang dalam pandangan masyarakat sangat tidak masuk akal, karena perbuatan kasus korupsi tersebut dilakukan secara bersamasama oleh ketiga terdakwa akan tetapi putusan yang dijatuhkan terhadap masing-masing 
terdakwa sangat berbeda. Ini jelas terdapat masalah dalam penanganan kasus yang dilakukan oleh Majelis Hakim Pengadilan Tipikor Semarang. Selain itu jika melihat perjalanan karir Majelis Hakim Pengadilan Tipikor Semarang yang menangani kasus tersebut cukup memprihatinkan, karena majelis hakim ini sering memberikan putusan-putusan yang sangat tidak maksimal bahkan kadangkala masih diputus bebas.

Perbedaan hukuman terhadap satu kasus yang dilakukan secara bersama sangat tidak masuk akal, itu terlihat dalam putusan yang dijatuhkan oleh Pengadilan Tipikor Semarang terhadap tiga terdakwa yang secara bersama melakukan tindak pidana penyalahgunaan APBD Sragen yaitu Untung Sarono Wiyono (Mantan Bupati Sragen), Kushardjono (Mantan Sekda Sragen), Sri Wahyuni (Mantan Kepala Dinas Pendapatan Pengelolaan Keuangan Aset Daerah (DPPKAD) Kabupaten Sragen, ketiga terdakwa tersebut diputus dengan hukuman yang berbeda-beda.

Dari ketiga putusan tersebut yang sangat mengherankan adalah putusan yang dijatuhkan terhadap Untung Sarono Wiyono yaitu putusan bebas, adanya putusan bebas tersebut memberikan gambaran bahwa kedudukan dan kekuasaan terdakwa dapat mempengaruhi suatu proses peradilan. Berlakunya disparitas penjatuhan hukuman di Pengadilan Tipikor Semarang disebabkan oleh hal-hal diluar peraturan perundangundangan, yaitu melihat kasus yang dihadapi oleh majelis hakim itu sendiri dan sikap dari terdakwa selama persidangan dan fakta-fakta yang ada di dalam persidangan, itulah yang membuat adanya perbedaan penjatuhan hukuman oleh majelis hakim.

\section{c. Urgensitas Pengadilan Tipikor}

Pemberantasan korupsi telah menempatkan korupsi sebagai kejahatan luar biasa, Tap MPR Nomor VIII/MPR/2001 tentang Rekomendasi Arah Kebijakan Pemberantasan dan Pencegahan Korupsi, Kolusi, dan Nepotisme mengatakan antara lain bahwa permasalahan KKN yang melanda bangsa Indonesia sudah sangat serius dan merupakan kejahatan luar biasa dan menggoyahkan sendi-sendi kehidupan berbangsa dan bernegara.
Konsideran Undang-Undang Nomor 31 Tahun 1999 sebagaimana diubah dengan Undang-Undang Nomor 20 Tahun 2001 tentang Pemberantasan Tindak Pidana Korupsi menggolongkan korupsi sebagai kejahatan yang pemberantasannya harus dilakukan secara luar biasa (penekanannya pada hukum acara). Alasannya korupsi terjadi secara meluas, tidak hanya merugikan keuangan negara, tetapi juga telah merupakan pelanggaran terhadap hak-hak sosial ekonomi masyarakat secara luas. Adapun Undang-Undang Nomor 30 Tahun 2002 tentang Komisi Pemberantasan Korupsi (KPK) pada bagian penjelasan umum menyebutkan korupsi yang meluas dan sistematis juga merupakan pelanggaran terhadap hak-hak sosial dan hak-hak ekonomi masyarakat. Karena itu, tindak pidana korupsi tidak lagi dapat digolongkan sebagai kejahatan biasa, melainkan telah menjadi suatu kejahatan luar biasa. Upaya pemberantasannya tidak lagi dapat dilakukan secara biasa, tetapi dituntut cara-cara yang luar biasa (penekanannya pada hukum materil dan hukum formal).

Salah satu upaya pemberantasannya ditetapkan melalui pembentukan Pengadilan Tindak Pidana Korupsi cara tersebut dituangkan dalam Pasal 53 Undang-Undang Nomor 30 Tahun 2002 tentang Komisi Pemberantasan Tindak Pidana Korupsi (KPK) yang ber bunyi "Dengan Undang-Undang ini dibentuk Pengadilan Tindak Pidana Korupsi yang bertugas dan berwenang memeriksa dan memutus tindak pidana korupsi yang penuntutannya diajukan oleh Komisi Pemberantasan Korupsi."

Dalam perjalanannya, telah diajukan judicial review berkaitan dengan Pasal 53 Undang-Undang Nomor 30 Tahun 2002 ke Mahkamah Konstitusi. melalui putusan perkara No. 012-016-019/ PUU-IV/2006, Mahkamah Konstitusi menyatakan Pasal 53 Undang-Undang Nomor 30 Tahun 2002 bertentangan dengan Undang-Undang Dasar 1945, namun tetap mempunyai kekuatan hukum mengikat sampai diadakan perubahan paling lambat 3 (tiga) tahun terhitung putusan diucapkan. Konsekuensinya, pembentuk Undang-Undang (Pemerintah dan DPR) harus membentuk Undang-Undang tentang 
Tabel 5. Perbandingan Putusan Majelis Hakim dalam Kasus Penyalahgunaan Uang APBD Sragen di Pengadilan Tipikor Semarang

\begin{tabular}{|c|c|c|c|}
\hline No & Putusan Perkara & Vonis & Legal Reasoning Hakim \\
\hline 1 & $\begin{array}{l}\text { Perkara No. 78/ } \\
\text { Pid.sus/2011/ } \\
\text { PN.Tipikor.Smg }\end{array}$ & Putusan Bebas & $\begin{array}{l}\text { Putusan bebas terhadap } \\
\text { mantan Bupati Sragen di } \\
\text { jatuhkan karena majelis ha- } \\
\text { kim yang menangani kasus } \\
\text { tersebut tidak memiliki in- } \\
\text { tegritas dan tidak bermoral }\end{array}$ \\
\hline
\end{tabular}

$2 \quad \begin{aligned} & \text { Perkara No. 79/ } \\ & \text { Pid.sus/2011/ } \\ & \text { PN.Tipikor.Smg }\end{aligned}$

Pidana penjara selama 4 tahun dan 6 bulan, denda 100 juta rupiah
Putusan terhadap mantan Sekda Sragen Kushardjono sudah sesuai dengan rasa keadilan masyarakat

\author{
Perkara No. 80/ \\ 3 Pid.sus/2011/ \\ PN.Tipikor.Smg
}

Pidana penjara selama 2 tahun dan 8 bulan, denda 50 juta rupiah
Putusan terhadap Sri Wahyuni mantan Kepala Dinas Pendapatan Pengelolaan Keuangan Aset Daerah (DPPKAD) Sragen, masih ringan, dan belum maksimal dalam penjatuhan hukuman

Sumber: Hasil Analisis Penulis Tahun 2014

Pengadilan Tindak Pidana Korupsi paling lambat 3 tahun sejak putusan Mahkamah Konstitusi dibacakan.

Setelah Putusan Mahkamah Konstitusi tersebut, kemudian di bentuk Undang-Undang No. 46 Tahun 2009 tentang Pengadilan Tindak Pidana Korupsi yang kemudian pada Januari 2011 mulai beroperasional Pengadilan Tipikor Semarang untuk menangani kasus-kasus korupsi yang ada di Jawa Tengah.

Adanya Pengadilan Tindak Pidana Korupsi di era reformasi saat ini tidak menjadikan perkara korupsi menghilang begitu saja, bahkan korupsi saat ini lebih parah jika dibandingkan dengan era orde lama dan orde baru, saat ini korupsi sudah merambah ke berbagai kalangan. Pembentukan Pengadilan Tipikor di daerah khususnya di Semarang merupakan upaya pemerintah dalam melaksanakan pemberantasan korupsi, akan tetapi saat ini Pengadilan Tipikor belum bisa melaksanakan tugasnya dengan baik, hal ini dibuktikan dengan beberapa kasus yang ditangani Pengadilan Tipikor Semarang masih banyak putusan yang dijatuhkan tidak maksimal. Masalah berikutnya adalah integritas dan moral hakim karena hakim sebagai pejabat yang memberikan putusan terhadap terdakwa koruptor masih mudah untuk disuap, hal ini yang membuat Pengadilan Tipikor kehilangan kewibawaanya. Urgensi adanya Pengadilan Tipikor semarang, parameternya adalah melihat perkara yang ada di Jawa Tengah Sebelum dan sesudah adanya Pengadilan Tipikor Semarang.

Berdasarkan data KP2KKN Jawa Tengah tahun 2014 dapat diketahui bahwa perkara korupsi di Jawa Tengah sebelum 
adanya Pengadilan Tipikor Semarang sangat memprihatinkan yaitu tahun 2009 sebanyak 425 perkara dengan kerugian Negara sebesar Rp. 308,709 Milyar dan tahun 2010 terdapat 174 perkara dengan krugian keuangan Negara sebesar 192,8 Milyar, ini yang membuat Jawa Tengah sebagai salah satu daerah yang tingkat korupsinya peringkat ke 3 di Indonesia, sedangkan setelah adanya Pengadilan Tipikor Semarang kasus yang ada di Jawa Tengah cenderung menurun, pada awal dibentuknya Pengadilan Tipikor Semarang yaitu pada tahun 2011 sebanyak 102 Perkara dengan kerugian keuangan Negara sebanyak Rp. 142,6 Milyar, akan tetapi di tahun berikutnya yaitu tahun 2012 dan tahun 2013 kembali mengalami peningkatan yaitu masing-masing sebanyak 215 dengan kerugian negara sebanyak Rp. 381 Milyar dan 222 perkara dengan kerugian negara Rp.110, 942 Milyar. Melihat perkara yang ada di Jawa Tengah ternyata korupsi cenderung menurun setahun setelah berdirinya Pengadilan Tipikor Semarang akan tetapi kembali lagi semakin banyaknya perkara di tahun berikutnya yaitu tahun 2012 dan 2013.

Berdirinya Pengadilan Tipikor di daerah didasari atas ketidakpuasan masyarakat dalam penegakan hukum terhadap kasus korupsi. Pendirian tersebut mempunyai makna dalam mewujudkan pemerintahan yang bersih dan bebas dari korupsi, kolusi dan nepotisme. Berikut hasil wawancari terhadap hakim ad hoc Pengadilan Tipikor Semarang": "Urgensi adanya Peradilan Tipikor di daerah timbul karena korupsi sekarang tidak hanya di pusat saja, justru di daerah juga semakin banyak, terutama yang paling rawan adalah korupsi APBD (anggaran pendapatan dan belanja daerah), pengadaan barang dan jasa, selain itu adanya Pengadilan Tipikor di derah juga menyangkut efektifitas, efesiensi waktu dan biaya. (Wawancara dengan Marsidin Nawawi, 27 Januari 2014).

Adanya Pengadilan Tipikor Semarang sebagai wujud untuk memutus rantai korupsi yang ada di daerah, perkembangan kasus korupsi sekarang sudah merambah ke berbagai lembaga di daerah, hal lain yang bisa dijadikan dasar akan keefektifan dan urgensi Pengadilan Tipikor ke depan adalah dengan melihat kondisi Peradilan Tipikor, sekarang peradilan kita diperparah dengan kurangnya kapasitas dan integritas para hakim yang baik, ini merupakan masalah yang dasar untuk terwujudnya peradilan yang bersih dan berwibawa. Upaya Pemerintah Indonesia untuk memberantas korupsi sudah sangat maksimal, berbagai peraturan perundangundangan dibuat sebagai landasan hukum dalam penegakan kasus-kasus korupsi, serta berbagai lembaga negara dibentuk sebagai pelaksana pemberantasan korupsi bahkan organisasi masyarakat dan lembaga swadaya masyarakat ikut ambil bagian untuk mengawasi pelaku-pelaku korupsi di negara ini.

Kinerja lembaga peradilan dianggap sebagian masyarakat tidak bersih dan kurang berwibawa, timbulnya pandangan ini disebabkan karena banyaknya penyalahgunaan wewenang di lembaga peradilan, keadaan yang demikian akan menghambat reformasi lembaga peradilan yang hendak mewujudkan sistem peradilan yang ideal dan sesuai dengan harapan masyarakat. Adanya peradilan tindak pidana korupsi di daerah merupakan wujud yang paling dasar untuk memberantas korupsi di daerah yang semakin berkembang banyak, melihat hal itu maka sangat mendesak untuk mendirikan peradilan tipikor di daerah.

Peradilan tipikor sebagai lembaga independen yang khusus menangani kasus korupsi ternyata belum juga memberikan efek jera bagi koruptor, disisi lain dapat dikatakan bahwa lembaga peradilan belum steril dari praktek korupsi. Sejak didirikan tahun 2011, tercatat ada 5 hakim tipikor yang diproses dalam kasus korupsi, yaitu:

1. Kartini Marpaung (Hakim Ad hoc Pengadilan Tipikor Semarang)

2. Asmadinata (Hakim Ad hoc Pengadilan Tipikor Palu)

3. Heru Kisbandono (Hakim Ad hoc Pengadilan Tipikor Pontianak)

4. Pragsono (Hakim Pengadilan Tipikor Semarang)

5. Setyabudi Tejocahyo (Hakim Pengadilan Tipikor Bandung)

6. (laporan tahunan Indonesia corruption watch, 2014: 6) 
Tabel 6. Jumlah kasus korupsi di Jawa Tengah

\begin{tabular}{|c|c|c|c|c|}
\hline No & Tahun & Jumlah Perkara & $\begin{array}{c}\text { Kerugian keuangan } \\
\text { negara }\end{array}$ & keterangan \\
\hline 1 & 2009 & 425 Perkara & Rp. 308,709 Milyar & $\begin{array}{l}\text { Total perkara tersebut yang } \\
\text { ada di seluruh kabupaten } \\
\text { atau kota di Jawa Tengah } \\
\text { sebelum adanya pengadilan } \\
\text { Tipikor }\end{array}$ \\
\hline 2 & 2010 & 174 Perkara & Rp. 192,8 Milyar & $\begin{array}{l}\text { Total Perkara yang ada di } \\
\text { seluruh kabupaten atau } \\
\text { kota di Jawa Tengah }\end{array}$ \\
\hline 3 & 2011 & 102 perkara & Rp. 142,6 Milyar & $\begin{array}{l}\text { Jumlah perkara sejak } \\
\text { berdirinya Pengadilan } \\
\text { Tipikor Semarang }\end{array}$ \\
\hline 4 & 2012 & 215 Perkara & Rp. 381 Milyar & $\begin{array}{l}\text { Total kasus yang ada di Jawa } \\
\text { Tengah }\end{array}$ \\
\hline 5 & 2013 & 222 perkara & Rp. 110,942 Milyar & $\begin{array}{l}\text { Jumlah keseluruhan perkara } \\
\text { yang ada di Jawa Tengah } \\
\text { dengan }\end{array}$ \\
\hline
\end{tabular}

Sumber: Informasi database KP2KKN Jateng Semarang Tahun 2014

Berkurangnya kewibawaan dan kepercayaan masyarakat terhadap lembaga peradilan antara lain disebabkan oleh lemahnya integritas moral hakim dan pejabat lembaga peradilan lain, putusan lembaga peradilan yang kontroversial, dan banyaknya putusan yang bertentangan dengan rasa keadilan masyarakat. Di Pengadilan Tipikor Semarang pelaksanaan untuk mewujudkan peradilan yang berwibawa adalah para pejabat di Pengadilan Tipikor Semarang menjalankan tugas sesusai dengan peraturan yang ada, selain itu ada pengawasan internal dari Mahkamah Agung sebagai upaya agar pejabat di lingkungan peradilan tipikor bekerja dengan baik dan tidak bertindak sewenang-wenang dalam pelaksanaan tugasnya. "Cara mewujudkan peradilan yang bersih dan berwibawa yaitu peradilan melalui para hakim mampu melakukan tugas peradilan yaitu menerima, memeriksa, dan mengadili perkara secara baik, mampu mengadili putusan yang benar-benar adil". (Wawancara dengan Jhon Halasan Butar-Butar,9 Januari 2014).

Berdasarkan hasil studi dokumentasi dalam Pasal 9 Peraturan Presiden Republik
Indonesia Nomor 55 Tahun 2012 Tentang Strategi Nasional Pencegahan Dan Pemberantasan Korupsi Jangka Panjang Tahun 2012-2025 Dan Jangka Menengah Tahun 2012-2014 disebutkan bahwa:

1. Dalam melaksanakan Stranas PPK, Kementerian/ Lembaga dan Pemerintah Daerah melibatkan peran serta masyarakat.

2. Pelibatan peran serta masyarakat sebagaimana dimaksud pada ayat (1), dapat dimulai dari tahap penyusunan, pelaksanaan, pemantauan, evaluasi, dan pelaporan.

3. Mekanisme pelibatan peran serta masyarakat sebagaimana dimaksud pada ayat (2), disesuaikan dengan karakteristik masing-masing Kementerian / Lembaga dan Pemerintah Daerah.

Sangat jelas bahwa peran masyarakat untuk memberantas korupsi sangat diperlukan, peran utama adalah ikut membantu agar masyarakat tidak melakukan budaya korup, selain itu masyarkat perlu melakukan pengawasan terhadap proyek-proyek yang rawan di korupsi, karena awal untuk membe- 
rikan jaminan agar terwujudnya negara yang bebas dari korupsi adalah dari masyarakat itu sendiri. Perwujudan pengadilan yang bersih dan berwibawa tidak terlepas dari kinerja hakim dalam memberikan putusan terhadap para terdakwa, dari situlah pengadilan akan terlihat kinerja yang sesungguhnya dilakukan oleh Pengadilan Tipikor. Peran lembaga peradilan adalah menyampaikan keputusan hukum yang bersifat mengikat.

Apa yang dilakukan oleh Artidjo (Hakim Agung) sebetulnya adalah kembang apinya Mahkamah Agung, karena untuk saat ini Mahkamah Agung masih dipandang jelek oleh sebagian masyarakat, sedangkan apa yang dilakukan oleh Artidjo merupakan semangat pemberantasan korupsi yang luar biasa, namun langkah tersebut belum di ikuti oleh hakim di Pengadilan Tipikor daerah. (Wawancara dengan Eko Haryanto, 24 Januari 2014 di).

Berdasarkan analisis historis konstitusi di Indonesia, adanya jaminan dan kepastian akan hakekat kebebasan dan kemandirian kekuasaan kehakiman sangat tergantung dengan penerapan dan pelaksanaan sistem politik. Dalam konstitusi secara eksplisit menyatakan kebebasan kekuasaan kehakiman, tapi penyimpangan masih begitu banyak terjadi, baik dalam konteks dimensi substansi maupun prosedural yang tidak memungkinkan terjadinya kebebasan dan kemandirian kekuasaan kehakiman.

Dalam melaksanakan kekuasaan kehakiman melalui badan peradilan, tidak lain dari pada melaksanakan fungsi peradilan sesuai dengan batas-batas kewenangan yang disebutkan Undang-Undang. Berdasarkan studi dokumen Pasal 2 ayat (2 dan 4), Pasal 3 ayat (1), Pasal 4 ayat (1), Pasal 5 ayat (1 dan 2) dan Pasal 10 Undang-Undang Nomor 48 Tahun 2009 menormatifkan beberapa asas hukum penyelenggaraan peradilan, intinya:

1. Peradilan dilakukan demi keadilan berdasarkan Ketuhanan Yang Maha Esa.

2. Peradilan menerapkan dan menegakkan hukum dan keadilan berdasarkan Pancasila.

3. Peradilan dilakukan dengan sederhana, cepat dan biaya ringan.

4. Dalam menjalankan tugas dan fungsinya hakim wajib menjaga kemandirian peradilan.

5. Pengadilan mengadili menurut hukum dengan tidak membeda-bedakan orang.

6. Hakim wajib menggali, mengikuti dan memahami nilai-nilai hukum dan rasa keadilan yang hidup dalam masyarakat.

7. Hakim harus memiliki integritas dan kepribadian yang tak tercela, jujur, adil, profesional dan pengalaman di bidang hukum.

8. Pengadilan dilarang menolak untuk memeriksa, mengadili dan memutus suatu perkara yang diajukan dengan dalih bahwa hukum tidak ada atau kurang jelas, melainkan wajib untuk memeriksa dan mengadilinya dan tidak menutup usaha penyelesaian perkara secara perdamaian.

Menjalankan kekuasaan kehakiman merupakan salah satu hal yang sangat sulit dilakukan di negara ini, karena oknum pejabat yang mengisi jabatan-jabatan tersebut belum semuanya mampu melaksanakan tugas dengan baik, ini timbul karena kompetensi untuk mewujudkan peradilan yang bersih dari pihak negara sendiri belum secara maksimal serius menanganinya.

Permasalahnya adalah pada posisi rekrutmen pejabat-pejabat yang mengisi di dalam kekuasaan kehakiman. Oleh sebab itu, perlu berbagai cara agar peradilan kita benarbenar mampu menjadi peradilan yang bersih dan berwibawa, agar terjaminya kepastian hukum di Negara Indonesia. Berikut penjelasan Sekretaris KP2KKN Jawa Tengah.Untuk mewudkan peradilan bersih dan berwibawa, cara yang paling utama adalah memperbaiki proses rekrutmen terhadap calon-calon hakim, karena saat ini untuk rekrutmen hakim masih kurang transparan dan perlu di perbaiki lagi selain itu perlu dilihat latar belakang atau rekam jejak calon-calon tersebut. (Wawancara dengan Eko Haryanto, 24 Januari 2014).

Berbagai peraturan perundangan yang mengatur kekuasaan kehakiman, masih belum memberi ruang dan atmosfir yang kondusif bagi independensi kekuasaan kehakiman. Banyak peraturan yang tidak selaras, tidak harmonis dan inkonsistensi dengan konstitu- 
si maupun satu dengan lainnya. Diantaranya ada yang mengandung berbagai kelemahan, karena mengandung multi penafsiran dan tidak bisa dilakukan enforcement (penegakan). Sementara mekanisme berbagai peraturan perundangan yang mendistorsi ketentuan dalam konstitusi. Intervensi atau pengaruh campur tangan dari kekuasaan pemerintah masih begitu jelas terlihat dan terasa. Dalam rezim ini, peradilan merupakan bagian dari kepentingan eksekutif, karena harus menjalankan direktiva dan mengamankan preferensi kepentingan penguasa dan kekuasaan.

Dengan dibentuknya Pengadilan Tipikor Semarang, perkara korupsi sekarang ini sudah mampu memberikan perbedaan warna dalam putusan terhadap koruptor, sebelum adanya Pengadilan Tipikor Semarang kasus korupsi yang di tangani oleh Peradilan Umum hanya memberikan putuan rata-rata 5 bulan terhadap para koruptor, sekarang setelah adanya penanganan perkara korupsi di Pengadadilan Tipikor Semarang putusan yang di jatuhkan oleh majelis hakim rata-rata 3,5 tahun, dilihat dari segi putusan terdapat peningkatan yang sangat baik, walaupun itu dinilai masyarakat masih belum maksimal. Sedangkan dalam perkara yang ada di Jawa Tengah sebelum adanya Pengadilan Tipikor yaitu tahun 2010 terdapat 174 perkara, setelah adanya Pengadilan Tipikor yaitu pada tahun 2011 di Jawa Tengah terdapat 102 kasus, ini mengalami penurunan kasus setelah adanya Pengadilan Tipikor Semarang.

Selain itu dalam proses penegakan hukum urgensi adanya Pengadilan Tipikor Semarang dikarenakan semakin banyaknya kasus korupsi yang ada di negara ini, selain itu perkara-perkara yang ada sekarang semakin kompleks, ini yang membuat Pengadilan Tipikor dibentuk di daerah. Efesiensi waktu dan biaya juga menjadi pertimbangan dalam pembentukan Pengadilan Tipikor di daerah. Upaya negara mewujudkan peradilan yang bersih dan berwibawa masih belum maksimal karena akar dari perwujudan tersebut masih banyak masalah, yaitu rekrutmen para hakim Pengadilan Tipikor Semarang, jika rekrutmen mampu mencari hakim-hakim yang berintegritas dan bermoral maka negara ini akan terjamin kepastian hukum dan hu- kum akan benar-benar adil ditegakkan. Melihat apa yang dihasilkan Pengadilan Tipikor Semarang saat ini masih perlu dipertahankan keadaanya karena memiliki peran yang sangat besar bagi penegakan korupsi di Negara Indonesia.

\section{Simpulan}

Kinerja proses penegakan hukum di Pengadilan Tipikor Semarang tahun 20112013 dapat dilihat dari: Jumlah kasus yang ditangani semakin banyak, dengan banyaknya kasus korupsi yang masuk di Pengadilan Tipikor Semarang, dapat membuktikan bahwa kinerja Pengadilan Tipikor Semarang dalam penegakan dan pemberantasan korupsi semakin serius. Putusan majelis hakim yang diberikan kepada terdakwa kasus korupsi, rata-rata jumlah putusan selama tahun 20112013 masih ringan, yaitu antara 0-4 tahun bahkan ada yang diputus bebas, ini membuktikan bahwa Pengadilan Tipikor masih lemah dan kurang maksimal dalam menjatuhkan hukuman kepada terdakwa kasus korupsi. Indepedensi hakim Pengadilan Tipikor dalam menangani kasus korupsi masih mudah dicampuri oleh urusan luar yaitu dengan orang yang mempunyai uang, itu dibuktikan dengan tertangkapnya hakim Pengadilan Tipikor Semarang karena kasus suap untuk meringankan hukuman.

Legal reasoning terhadap adanya disparitas penjatuhan hukuman bagi koruptor: Disparitas penjatuhan hukuman bagi terdakwa kasus korupsi tidak bisa dihindarkan dan pasti dipakai oleh majelis hakim Pengadilan Tipikor Semarang karena hakim melihat kasus yang ditangani, sikap terdakwa selama persidangan dan fakta-fakta yang ada di dalam persidangan dan setiap terdakwa pasti berbeda, itu yang menyebabkan terjadinya disparitas penjatuhan hukuman oleh hakim. Adanya disparitas penjatuhan hukuman dalam kasus penyalahgunaan uang APBD Mantan bupati Sragen Untung Wiyono di vonis bebas, itu terjadi karena ditangani oleh majelis hakim yang tidak berintegritas dan tidak bermoral.

Urgensi Pengadilan Tipikor Semarang dalam mewujudkan peradilan yang bersih 
dan berwibawa: Urgensi adanya Pengadilan Tipikor di daerah khususnya di Semarang didasari atas ketidakpuasan masyarakat dalam penegakan hukum terhadap kasus korupsi. Pendirian tersebut mempunyai makna dalam mewujudkan pemerintahan yang bersih dan bebas dari korupsi, kolusi dan nepotisme. Cara mewujudkan peradilan yang berwibawa yaitu lembaga peradilan dengan pejabat yang ada di dalamnya termasuk hakim dan panitera bekerja komitmen terhadap pemberantasan korupsi.

\section{Daftar Pustaka}

Asshiddiqie, J. 2013. Pengadilan Khusus. Juli. HIm 1-17 Chaerudin. 2008. Strategi Pencegahan dan Penegakan Hukum Tindak Pidana Korupsi. Bandung: Refika Aditama.

Hadjon, P.M. 2011. Pengantar Hukum Administrasi Indonesia. Yogyakarta: Gajah Mada University Press.

Hartanti, E. 2005. Tindak Pidana Korupsi. Jakarta: Sinar Grafika.

Miles, M.B., and Huberman A.M. 2007. Analisis Data Kualitatif. (Penerjemah Tjetjep Rohendi Rohidi) Jakarta: UI- Press

Moleong, L.J. 2007. Metodelogi Penelitian Kualitatif. Bandung: PT Remaja Rosdakarya

Nadapdap, B. 2003. Mendambakan Putusan Hakim Yang Berwibawa. Jurnal Keadilan. Volume 3 No- mor 2.

Santoso, T. 2011. Urgensi Pembenahan Pengadilan Tindak Pidana Korupsi Dalam Mewujudkan Good Governance. Jakarta: BPHN

Soekanto dan Mamudji. 1986. Pengantar Penelitian Hukum (Cetakan ke-1). Jakarta: UI Press.

Zulva, E.A. 2011. Pergeseran Paradigma Pemidanaan. Bandung: Lubuk Alung

Undang-Undang Dasar Republik Indonesia 1945

Undang-Undang No. 46 Tahun 2009 Tentang Pengadilan Tindak Pidana Korupsi

Undang-Undang No. 30 Tahun 2002 Tentang Komisi Pemeberantasan Korupsi

Peraturan Presiden No. 55 Tahun 2012 Tentang Strategi Nasional Pencegahan dan Pemberantasan Korupsi Jangka Panjang Tahun 2012-2025 dan Jangka Menengah Tahun 2012-2014

Putusan Mahkamah Konstitusi No.012-016-019/PUU/ IV/2006

Cetak Biru Pembaruan Peradilan 2010-2035, Mahkamah Agung Republik Indonesia 2010

h t t p : / / w w w . t e m p o . c o / r e a d / news/2012/11/08/063440456/MantanBupati-Sragen-Segera Dijebloskan-ke-Penjara,

www.antikorupsi.org/sites/antikorupsi.org/.../trenvoniskorupsi2013.pdf,

(http://hukum.tvonenews.tv/berita/ view/72679/2013/07/22/lagi_hakim_ tindak_pidana korupsi_jadi_tersangka_ kpk.tvOne, accessed, 14 Desember 2012) 